Clemson University

TigerPrints

May 2020

\title{
"It felt like walking through a night sky": Managing the Visitor Experience During Biologically-Based Nighttime Events
}

Caitlin Michelle Henry

Clemson University, caithenry56@gmail.com

Follow this and additional works at: https://tigerprints.clemson.edu/all_theses

\section{Recommended Citation}

Henry, Caitlin Michelle, "'It felt like walking through a night sky": Managing the Visitor Experience During Biologically-Based Nighttime Events" (2020). All Theses. 3341.

https://tigerprints.clemson.edu/all_theses/3341

This Thesis is brought to you for free and open access by the Theses at TigerPrints. It has been accepted for inclusion in All Theses by an authorized administrator of TigerPrints. For more information, please contact kokeefe@clemson.edu. 
"IT FELT LIKE WALKING THROUGH A NIGHT SKY": MANAGING THE VISITOR EXPERIENCE DURING BIOLOGICALLY-BASED NIGHTTIME EVENTS

\begin{tabular}{c} 
A Thesis \\
Presented to \\
the Graduate School of \\
Clemson University \\
In Partial Fulfillment \\
of the Requirements or the Degree \\
Master of Science \\
Parks, Recreation, and Tourism Management \\
Caitlin M. Henry \\
May 2020 \\
Jeffrey C. Hallo, Committee Chair \\
J. Adam Beeco \\
Matthew T. J. Brownlee \\
William C. Norman \\
\hline
\end{tabular}




\begin{abstract}
Biologically based nighttime events (BBNEs) are events and activities specifically related to nighttime biological phenomena, and are becoming increasingly popular. As nighttime recreation in parks and protected areas increases, managers must implement policies and frameworks that maintain both the visitor experience and natural darkness and soundscapes. The nationally renowned Congaree National Park (CONG) Fireflies Festival celebrates the annual fireflies mating season, and has witnessed increased event visitation. The Fireflies Festival currently does not limit visitation during the festival or charge a fee, even though these are actions implemented at the one other national park that has synchronous fireflies. Over the past year, visitation rates have forced park managers to modify how they manage visitation during the firefly mating season. Specifically, the park implementing a designated trail with numerous restricted items (i.e., glow-sticks, cameras with flash photography, and flashlights without red cellophane coverings) and actions to manage the natural phenomena more like a festival event, whereas prior to the visitation spikes there were no restrictions. Visitor perceptions of these actions are currently unknown.
\end{abstract}

This study examined visitor motivations for attending the event and their perceptions of crowding. A total of 314 online surveys and 27 phone interviews were conducted, with a response rate of $61.7 \%$ for the surveys and $55.1 \%$ for the phone interviews (estimated $\pm 5.4 \%$ confidence interval for survey results at a $95 \%$ confidence level). The demographics and factors like extraordinariness and unique experiences for 
festival attendees aligned with nature-based visitors (Kruger, Saayman, \&Hull, 2019; Kruger \& Saayman, 2017). The organization of the Fireflies Festival and Fireflies Trail, along with use density of crowds were the greatest potential indicators of high quality visitor experiences. Overall, the findings indicate that while novelty-seeking motivations could predict some of the expected levels of crowding based on Surprise and Change in Routine factors, these motivations account for little of the variance. BBNE participants also reported that they expected to feel more crowded at the festival than they experienced.

The overwhelmingly positive response from CNP Fireflies Festival attendees suggest that the festival, and BBNEs overall, could be an untapped potential for tourism development. Many people left the festival viewing the park as a "hidden gem" that people want to visit again. These research findings could be used to catalyze potentially untapped tourism development in rural or low-income areas while also educating visitors about conservation issues on both a local and national scale. This study expands on night recreation research and fills in some of the literature gap on nighttime event management in a national park setting. 


\section{DEDICATION}

To my friends, family, and everyone who stuck with me through this process. Thank you. 


\section{ACKNOWLEDGMENTS}

This thesis would not have been possible without the help of many others. Thank you to my committee chair, Dr. Jeff Hallo, for taking a chance on both me and this project, and for pushing me to produce the best product I can. I also want to recognize the contributions of Dr. Matt Brownlee for bringing me into the Parks Solutions Lab and for offering his guidance with statistical analyses. Thank you to my other committee members, Dr. Bill Norman and Dr. Adam Beeco, for their valuable contributions. Thank you to Michael Blacketer for helping me understand statistical analysis, without whom I would not have understood the data I collected.

Much appreciation for the other graduate students in the Parks Solutions Labespecially John, Bess, and Brian - for not getting too annoyed at my antics and unusual poem contributions to the lab whiteboard. Thank you trivia crew for helping me stay sane this last semester by giving me an outlet outside of graduate school. Lastly, thank you Dr. Tom Lekan and the staff past and present at Congaree National Park for catalyzing my love for the park. 


\section{TABLE OF CONTENTS}

Page

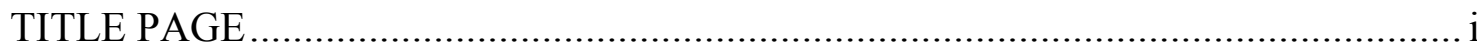

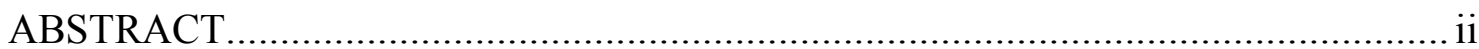

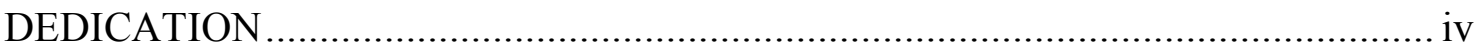

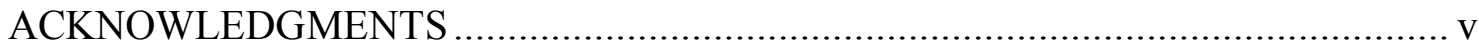

TABLE OF CONTENTS .......................................................................... vi

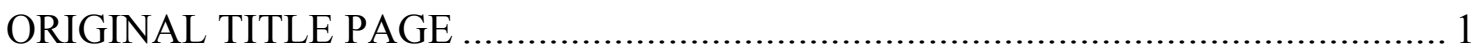

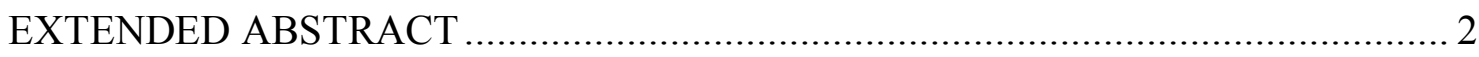

Chapter One: INTRODUCTION .............................................................. 3

Problem Statement and Research Questions ................................................ 5

Chapter Two: LITERATURE REVIEW .......................................................... 7

Motivations ...................................................................................... 7

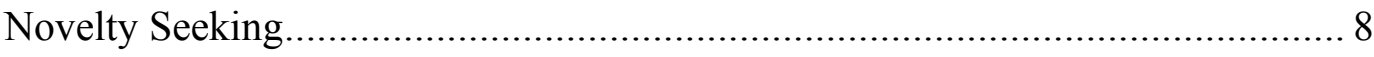

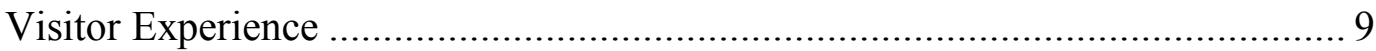

Carrying Capacity and Visitor Use Management Frameworks........................ 11

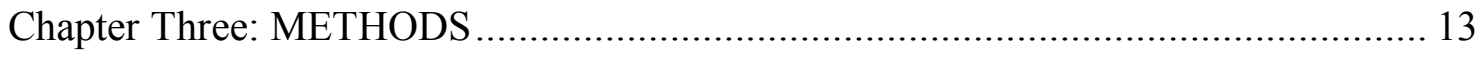

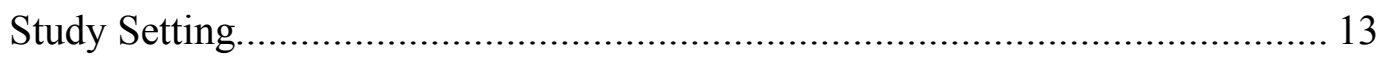

Study Population, Visitor Survey, and Visitor Interview............................. 15

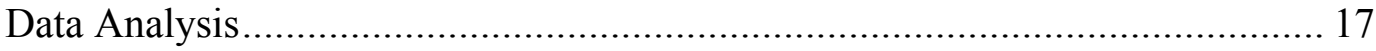

Chapter Four: RESULTS..................................................................... 20

Description of the Sample .................................................................. 20

BBNE Participants' Motivations, Trip Characteristics, and Sociodemographics (RQ1) ............................................................. 20

Indicators That Lead to Quality BBNE Experiences (RQ2) ........................... 22 
Event Motivations and Novelty Seeking Motivations (RQ1 \& RQ3) ................ 24

Perceptions of Crowding (RQ3) ............................................................ 25

Attitudes Toward Current and Potential Management Practices (RQ4)............. 28

Chapter Five: DISCUSSION AND CONCLUSION .......................................... 30

Resource Concerns and Recommendations .............................................. 31

Visitor and Motivation Types................................................................ 33

Potential Implications for Tourism Development of BBNEs........................... 34

Chapter Six: LIMITATIONS AND FUTURE RESEARCH ................................ 36

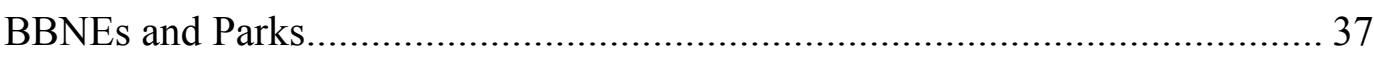

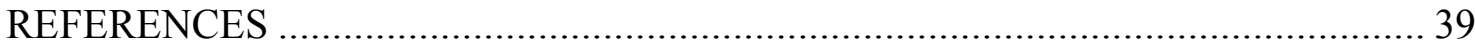

Appendix A: TABLES ......................................................................... 51

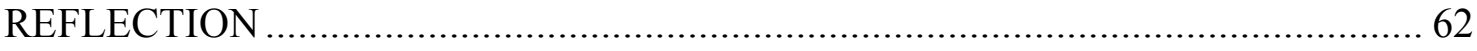




\title{
ORIGINAL TITLE PAGE
}

"IT FELT LIKE WALKING THROUGH A NIGHT SKY": MANAGING THE VISITOR EXPERIENCE DURING BIOLOGICALLY-BASED NIGHTTIME EVENTS

Cait M. Henry ${ }^{1}$, Jeffrey C. Hallo ${ }^{*}$, Michael Blacketer ${ }^{1}$, Matthew T.J. Brownlee ${ }^{1}$, William C. Norman ${ }^{1}$, J. Adam Beeco ${ }^{2}$

\author{
${ }^{1}$ Department of Parks, Recreation, and Tourism Management \\ Clemson University \\ Clemson, SC, USA
}

${ }^{2}$ Natural Sounds \& Night Skies Division National Park Service Fort Collins, CO, USA

*Corresponding author may be reached at jhallo@clemson.edu 


\section{EXTENDED ABSTRACT}

Nighttime activities and events specifically related to natural phenomena are becoming increasingly popular. As nighttime recreation in parks and protected areas increases, managers must implement policies and frameworks that maintain both the visitor experience and natural darkness and soundscapes. The Congaree National Park Fireflies Festival celebrates the annual fireflies mating season, and after national renown for this event the park has witnessed increased visitation. Over the past year, visitation rates have forced management to implement a designated trail to enhance the visitor experience while reducing crowding on the boardwalk and manage the natural phenomena more like a festival event than an outdoor recreation opportunity. Visitor perceptions of these actions are currently unknown. Therefore, this study examined visitor motivations for attending the event and their perceptions of crowding to distinguish whether festival attendees had higher tolerances of crowding at a nature-based event within a national park. This study implemented an online survey and phone interviews to distinguish what factors at the Fireflies Festival bolster or degrade visitor experiences and to gauge perceptions of current and future management actions. Moreover, this study sought to understand visitor motivations to attend BBNEs and employed the novelty-seeking and event (festival) motivations scales. This study expands on night recreation research and fills in some of the literature gap on nighttime event management in a national park setting. 


\section{Chapter One:}

\section{INTRODUCTION}

Americans love their national parks. In 2019 alone, the National Park Service (NPS) reported 2019 had 327.5 million visits to their public lands (NPS, 2020). Increased or high visitation levels can negatively impact fragile ecosystems within these public lands (Park, Daniels, Brayley, \& Harmo, 2010). The notion of "loving the parks to death" has gained popularity in recent years, which corresponds to high levels of visitor use that easily degrade the landscape and negatively impact the wondrous but finite natural resources and related visitor experiences that parks aim to protect.

The ability to experience night resources, and the protection of these experiences, are also important to achieve park missions. The 1916 Organic Act mandated the NPS's dual mission to "conserve the scenery and the natural and historic objects and the wildlife therein and to provide for the enjoyment of the same in such manner and by such means as will leave them unimpaired for the enjoyment of future generations" (Organic Act, 1916, p.1). Nuisance lighting and light pollution affect a large portion of the global night sky, so areas with few artificial light sources - like the wide expanses of national parks and protected areas - will become more important to conserve (Smith \& Hallo, 2013; Duriscoe, 2001). Management of the nighttime visitor experience may become more critical as natural darkness becomes scarcer due to light pollution, possibly influencing more people to seek out opportunities to experience it and other night- dependent resources (Manning et al., 2015). 
Nighttime events focused on biologically-based resources can act as a novel draw for park visitors. Multiple National Parks offer site-specific nighttime programs and events, from the Bat Flight Program at Carlsbad Caverns National Park to synchronous firefly events at both Congaree and the Great Smoky Mountains National Parks (NPS 2019a, 2019b, \& 2019c). These events are not limited to National Park units, but are also held by commercial outfitters and state parks, and can be points of interest in international travel tourism (Beh \& Bruyere, 2007; Hsu, Tsai, \& Wu, 2009). While these events allow for unique visitor experiences that are not possible elsewhere, there may be some visitor experience or natural resource impacts that go unnoticed until they are heavily degraded (Dangi \& Gribb, 2018). Because of this, proactive research can lead to proactive management implementations that would allow for ongoing informed use (Manning, 2011; Manning \& Lawson, 2002).

Attendees at biologically-based nighttime events (BBNEs) may be distinct from those who visit the same park or tourism site during the daytime. Nighttime events may attract people with time constraints that cannot normally visit during the daytime or prefer to recreate as a family. BBNEs are often nontraditional experiences that involve hyper-seasonal activity of nocturnal species, like the Ghost Mushrooms (Omphalotus nidiformis) in Australia and the Queen of the Night flower (Peniocereus greggii) in Arizona (ForestrySA, 2019; Tohono Chul, 2019). Unique experiences that occur only at certain locations can also increase interest from novelty seekers (Chang, Wall, \& Chu, 2006). In summary, there are multiple factors that may influence visitor motivation to attend BBNEs, and these could contribute to differing motivations for day and nighttime 
users (Beeco, Hallo, Baldwin, \& McGuire 2011). These differences may be valuable for understanding visitor motivations to seek out and participate in these unique events.

BBNEs present substantial challenges for parks to provide visitor experiences that are enjoyable yet sustainable. Smith and Hallo (2013) found that although many parks offer access to night resources, few parks had facilities or staff at night—which became a safety concern for the park managers. Furthermore, high concentrations of nighttime visitors can negatively affect the natural darkness and natural quiet which nocturnal animals heavily rely upon (Gaston, Bennie, Davies, \& Hopkins, 2013; Ware, McClure, Carlisle, and Barber, 2015). Increased anthropogenic light and sound also negatively affect other park visitors (Beeco, Hallo, Baldwin, \& McGuire 2011; Duriscoe, 2001). These challenges put greater strains on nighttime resources, which must be managed accordingly.

Research provides objective information on visitor perceptions and preferences that can allow managers to better influence visitor use (Manning, 2011). As one of the mandates for the NPS is to provide enjoyable recreation, understanding the visitor experience and satisfaction levels are vital for park management practices (Fefer, UriosteStone, Daigle, \& Silka, 2018). This need for understanding extends into nighttime leisure recreation research.

\section{Problem Statement and Research Questions}

To prevent shifting satisfaction levels, park managers should monitor nighttime resource impacts and visitor experiences. As natural darkness becomes scarcer, it is 
important to understand how recreational activities like BBNEs could affect this decreasing resource, however, there is little information on these issues.

The current paper seeks to address these questions:

1) What are BBNE participants' motivations, trip characteristics, and sociodemographic characteristics? Where comparable, how do these differ from typical daytime park visitors?

2) What are the factors (i.e., indicators) that lead to quality BBNE experiences?

3) What are participants' perceptions of crowding, and what levels of it are acceptable? Moreover, how are these related to motivations to seek novel experiences?

4) What are BBNE participants' perceptions toward current and potential management approaches related to the visitor experience, crowding, and crowd control at BBNEs? 


\section{Chapter Two:}

LITERATURE REVIEW

\section{Motivations}

Understanding motivations is vital when managing people, yet research on motivations within the social science realm overflows with competing perspectives on what motivations are and how strongly they influence behavior (Aunger \& Curtis, 2013; Bernard, Mills, Swenson, \& Walsh, 2005). Leisure needs are not static, but vary as functions of leisure experiences (Iso- Ahola \& Allen, 1982). Therefore, needs are often clustered together based on individual differences in activity satisfaction and leisure behaviors (London, Crandall, \& Fitzgibbons, 1977). Tourism motivations are a subsection of leisure motivation, in that leisure travel is an important component of tourism. Although no overarching theoretical framework or sociological perspective of travel motivation exists (Hsu, Cai, \& Li, 2010), some models are used almost ubiquitously, like push-pull motivations. Push motivations create the desire to travel and pull motivations explain the choices made (Dann, 1981). Although new models for pushpull motivations have arisen within the last decade, the underlying motivational theory

remains the same (Kruger, Saayman, \& Hull, 2019: Šimková \& Holzner, 2014; Xu \& Chan, 2016).

Festival (event) and nature-based event motivations. Events and festivals are tourist attractions to local areas (Getz, 1991). Motivations for festival and event attendance can stem from the events themselves or can stem intrinsically from the 
participants. Uysal, Gahan, and Martin (1993) expanded on the escape-seeking tourism motivation framework of Iso-Ahola in their case study of a "down home" family-oriented event, creating an Event (Festival) Motivation Scale that divides into five factor groups: escape, excitement or thrills, event novelty, socialization, and family togetherness. They found that both repeat and first-time visitors highly valued event novelty and socialization as motivations (Uysal, Gahan, \& Martin, 1993).

Natural event motivations identified by Kruger, Saayman, and Hull (2019) found only three push motivation factors: lifestyle and nature experience, annual commitment and social interaction, and unique experience and escape; with one pull motivation factor of education and photography. They translated these motivation factors into a typology for natural event attendees that includes Novelists, Naturalists, Enthusiasts, and Escapists (Kruger, et al., 2019). These differences reiterate that nature-based tourists are not always outdoor recreationalists who regularly visit national parks (Mehmetoglu, 2007). However, one important limitation is that very little research within the United States focuses on natural event attendance motivations or perceptions of crowding (Kruger, Saayman, \& Hull, 2019; Kruger \& Saayman, 2017).

\section{Novelty Seeking}

The concept of novelty is defined as an experience that differs from every day, usually in the form of stimuli or innovation (Mitas \& Bastiaansen, 2018). Believed to be one of the aspects that makes travelling enjoyable, novelty consists of four different dimensions: a change in routine, thrill, surprise, and boredom alleviation (Lee \& 
Crompton, 1992). Similar to other leisure motivations, levels of novelty differ individually (Mitas \& Bastiaansen, 2018). Lee and Crompton (1992) defined novelty seeking for tourism. Their Novelty Seeking in Tourism Scale is still cited in current tourism research because the researchers internally validated the scale prior to publication (Gursoy, Uysal, Sirakay-Turk, Ekinci, \& Baloglu, 2015). The continuation of motivation research often occurs through the novelty-seeking lens. Mitas and Bastiaansen (2018) state that novelty can affect between one third and one half of the emotions felt when travelling. Novelty can also strengthen intentions to revisit the same destination, which could be due to increased familiarity and decreased risk from the environment (Jang \& Feng, 2007; Lehto et al., 2006). Because events and festivals are usually novel experiences, connections between novelty and positive emotions focus on the "specialness" of the event (Geus, Richards, \& Toepoel, 2016). This specialness is compounded with the uniqueness of each festival, so that motivations to attend one may differ from the motivations to attend another festival event (Scott, 1995). These links could be used to guide management frameworks that aim to satisfy visitors by maintaining certain levels of novelty for both first time and repeat visitors.

\section{Visitor Experience}

Visitor experiences to public lands encompasses perceptions, reactions, and emotions that visitors have during the entire trip experience, which includes time spent before and after the visit, along with the event duration (IVUMC, 2016). Public land managers are often concerned with providing quality visitor experiences, as these allow 
for parks to "contribute their full potential to the enjoyment of society" while spurring conservation advocacy for natural resources (Manning, 2001, p.94). Visitor satisfaction occurs when visitors' desires are fulfilled, and these are dependent on a multitude of motivations and normative standards, including perceived crowding (Kuentzel \& Heberlein, 2003). For public land managers charged with events or festivals to understand visitor expectations, they must first understand event experiences (Geus, Richards \& Toepoel, 2016). Event experiences rely on cognitive and physical engagement, novelty, and affective engagement with event managers (Geus, Richards, \& Toepoel, 2016). Therefore, crowd management is an imperative aspect of event experience.

Crowding. Some research at festival events has shown that crowding allowed for positive experiences like relaxation and people-watching (Anderson, Kerstetter, \& Graefe, 1998; Mowen, Vogelsong, \& Graefe, 2003). Although research on festival crowding perceptions show that high levels of crowding in non-competing open areas is generally accepted, NPS public land managers must also monitor natural resource impacts to avoid unnecessary degradation (Mowen, et al., 2003; Park, et al., 2010). Therefore, visitor use levels are managed through visitor capacity frameworks that that aim to create thresholds of use that will not negatively impact natural resources (Whittaker, et al., 2011; IVUMC, 2016).

Furthermore, perceptions of crowding can be influenced by mediating factors like place attachment, and research at non-PPAs suggest that event attendees hold a higher tolerance for crowding (Wickham \& Kerstetter, 2000). This differs significantly from 
research on crowding and place attachment in parks and protected areas, where visitors with high levels of place attachment desired "wildland" experiences where they encounter less visitors (Warzecha \& Lime, 2001). Crowding at events or festivals and crowding during outdoor recreation are not the same, so understanding both can allow for integration of techniques to best manage an event in an outdoor recreation setting (Anderson, et al., 1998).

\section{Carrying Capacity and Visitor Use Management Frameworks}

The concept of visitor capacity is a major component in management frameworks because it directly relates to resource and experiential degradation (IVUMC, 2019; Marion, 2016). Visitor capacity and carrying capacity are synonymous and defined as the amount and type of human use that an area can maintain while sustaining desired natural and cultural resource conditions, management objectives, and visitor experiences (Whittaker, et al., 2011). Visitor capacity is made up of indicators and thresholds (Manning, 2001). These monitor impacts, which are human-caused changes to natural areas. Impacts can be both positive and negative, and affect both natural resources and social conditions (Marion, Leung, Eagleston, \& Burroughs, 2016).

Visitor capacities are not visitor use limits based solely on natural resource protection, but also the quality of recreation opportunities (Haas, 2001; Manning, 2011; Whittaker, et al., 2011). Furthermore, physical use levels do not always correlate to perceptions of overcrowding. Because of this, many researchers focus on perceived crowding over use levels (Kuentzel \& Heberlein, 2003). Crowding norms are 
conglomerates of visitors' perceptions of use within a specified area or zone on public land where degradation of natural and cultural resources directly occurs because of visitor use (Manning, 2001). However, visitor perceptions can change over time, between different cultural backgrounds, or as social values change, and therefore normative crowding approaches should evolve alongside crowding perceptions (Burns, Arnberger, \& von Ruschkowski, 2010; McCool \& Freimund, 2015). Visitor capacity management applications include monitoring changes in perceptions of crowding while visitation increases (Kuentzel \& Heberlein, 2003), researching crowding norms for thresholds (Manning, Lime, Hof, \& Freimund, 1995), and enhancing utility of impact assessments (D'Antionio, Monz, Newman, Lawson, \& Taff, 2013; Fefer, Urioste-Stone, Daigle, \& Silka, 2018).

The Interagency Visitor Use Management Council (IVUMC) recently formed to create a ubiquitous Visitor Use Management (VUM) Program. The current VUM framework emphasizes a scale of analysis approach to visitor use management, and it implements indicators and standards of quality (IVUMC, 2016; Marion, 2016). VUM aims to achieve desired visitor experiences and resource conditions through managing visitor use (Miller, Leung, \& Kays, 2017). 


\section{Chapter Three:}

\section{METHODS}

Online surveys and semi-structured phone interviews were utilized via a convergent mixed methods design (Creswell \& Plano Clark, 2017). A congruent mixed methods design involves collecting both qualitative and quantitative data, which is then analyzed separately before the results are combined to compare the results (Cresswell \& Plano-Clark, 2017). The integration of both qualitative and quantitative data enhances the value of the research by assessing the validity of the findings within both sets of data and further explain the findings within one data set (Fetters, Curry, \& Creswell, 2013). The research team implemented this design for myriad reasons, including the limited time frame for data collection, the research team contained individuals who are skilled in both quantitative and qualitative data analysis, and allowed for a more complete understanding of the research problem. Methods utilized within the study, study setting and population, and data analysis are expanded upon in greater detail within this section.

\section{Study Setting}

Congaree National Park (CONG) is home to one of three species of synchronous flashing fireflies within North America, Photuris frontalis. Located half an hour to the southeast outside Columbia, South Carolina, CONG allows for visitors to experience designated Wilderness while being close to an urban center. Although CONG has witnessed an almost 60\% increase in visitation since the 2016 NPS Centennial Year, visitation is still relatively low compared to other national parks, with just over 145,000 
recreation visitors in 2018 (https://irma.nps.gov/Stats/Reports/Park).Visitation spikes during the annual synchronous fireflies mating season, especially after the 2018 festival received national recognition heralding CONG as "the best place in North America to see synchronous fireflies" (Billock, 2018, p.1).

Because of this national praise, visitor demographics extend beyond the state. During the peak weekend of the 2018 fireflies viewing event, there was a mile-long line of parked cars along the entrance road after the parking lots filled up (G. Cunningham, 18 October 2018). Because of this high volume of people, the physical parking capacity was reached during peak viewing days, which increased conflict and safety concerns. However, visitors' perceptions of the experience and associated management challenges are unknown.

The Fireflies Festival is located around the Harry Hampton Visitor Center, following the bluff-line around the building for ample firefly viewing. Since this area is firefly habitat, festival attendees have a truly immersive experience. CONG accommodated for recently published reports on the fireflies and visitor input from the 2018 festival and modified their organization of the festival. For example, park management did install low-watt lights around the trail for visitor safety, however, these lights were covered in red cellophane in order to not disturb the fireflies. The Fireflies Trail is a one-way trail around a quarter mile in length. Attendees are recommended to traverse the trail as many times as they please as long as they keep moving. There is one area along the trail set up for rest and reflection near the trail entrance, which consists of a couple of picnic tables. Here, visitors can spend as much time as they please, but as use 
density increased on the trail, it is more difficult to view the fireflies when sitting down. There are no food trucks or other concessionaires at the Fireflies Festival, although there are EMTs on site and an additional portable toilet, although most people preferred to use the restrooms adjacent to the visitors' center. The visitors' center stays open until 10:00 p.m. for the duration of the Fireflies Festival. Festival attendees could stay in the park later than this and continue to use the Fireflies trail or boardwalk (which between 7:30 10:00 p.m. is the designated area for attendees with limited mobility or other disabilities), however, a majority of people leave the festival around ten or earlier to avoid traffic.

\section{Study Population, Visitor Survey, and Visitor Interview}

Data from an online survey and semi-structured phone interviews were collected between May $10^{\text {th }}$ and May $27^{\text {th }}$ at the 2019 CONG Synchronous Fireflies Festival. Sampling efforts occurred by stationing a researcher on 10 of the 18 days near the entrance to the CONG Visitors' Center. This site was specifically identified in conjunction with CONG staff as a site that would provide a good representation of visitor use during the Festival. A parallel sample of BBNE attendees were obtained, with a priority given to the quantitative sample due to the emphasis on festival management. Based on the researcher's availability, all festival visitors 18 or older were asked to participate by providing their name and email information for an online survey or their phone number for an interview. Because most festival attendees visited in groups, only one person was randomly selected to participate in the survey (i.e., birthday closest to the data collection day). Data collection times occurred between 8:00-11:00 pm. Sampling 
efforts included both peak (weekends) and non-peak (weekdays) use days. This sampling approach provided a representative sample of event visitors by balancing low and high use times over the period. The survey was administered online through Qualtrics software the day after in-park contact. The survey was linked via email to each participant, and two reminders were emailed during a two-week period from initial contact after participants exited the Fireflies Trail at the festival. Due to the late timeframe of the festival, surveys were not completed on site.

The survey included two preexisting motivation scales, along with questions from the Pool of Known Questions from the NPS Social Science Office (NPS, 2012). A modified version of the Event (Festival) Motivations Scale created by Uysal, Gahan, and Martin (1993) was used to measure motivations for event-based tourists to BBNEs. Three items within the Excitement/Thrills domain were excluded because they were not as relevant to BBNEs (i.e., related to food or arts and crafts). A modified version of Lee and Crompton's (1992) Novelty Seeking in Tourism Scale was used to see if novelty seeking could be a motivation relating to BBNE participation. This excluded the Thrills dimension because it is not as applicable to this BBNE as the dimension focused more on adrenaline-based adventures (i.e., I enjoy experiencing a sense of danger on vacation; I would like to be on a raft in the middle of a wild river at the time of spring floodwaters). Other survey questions pertained to the overall visitor experience at the Festival, encompassing their motivations to attend, perceptions of festival management, time spent parking and walking to the festival entrance, and other factors that added or detracted to their experience. Visitor attitudes toward management were measured by asking the 
extent to which respondents favored or opposed a series of alternative management practices or services designed to maintain thresholds as well as the current practice. Potential management alternatives and services were identified in coordination with park staff, and include a range of common visitor management practices (i.e., rules and regulations, permitting, use limits).

Semi-structured phone interviews used a modified Seidman approach and asked in-depth questions to visitors on topic prompts similar to the online survey (Seidman, 2019). Outreach to the participants occurred the day after initial contact at the festival. Interviewees verbally consented to the brief interviews, which were then audio recorded. In order to merge these two databases, parallel questions were asked within the survey and interview script (Cresswell \& Plano-Clark, 2017). Participants were asked questions on trip characteristics and event motivations, the factors that lead to high quality visitor experiences, a question on perceived crowding and its relation to novel events, and current and future management practices. These interviews are meant to provide mixedmethods data that can add richness and depth to the quantitative survey findings (Hallo, Manning, \& Stokowski, 2009).

\section{Data Analysis}

Researchers conducted the survey data analysis in three main steps. First, data was stored, managed, and analyzed. Secondly, incomplete responses were removed before calculating descriptive statistics, chi-square and post hoc analyses for BBNE visitor characteristics and to understand whether there were statistical differences 
between festival attendees and general park visitors. Then, a confirmatory factor analysis (CFA) was implemented on the two motivation scales to validate the scales for use in this study. For the phone interviews, the researchers transcribed each interview before implementing open and axial coding to define and describe themes that were then used to find potential indicators for quality visitor experiences and visitor perceptions of the current and three potential management actions.

Survey data were stored and managed using Microsoft Excel 2016, and analyzed in SPSS Statistics 24 Software. Incomplete responses were removed from the data set, and frequencies were calculated for each survey question. Frequencies, percent of responses, means, and standard deviations (SD) were reported where appropriate. Openended response questions were coded into main themes and quantified into frequencies (i.e., number of times the theme was mentioned; Hallo, Manning, \& Stokowski, 2009). Chi square and post hoc analyses were run on the questions about visitor demographics, which were copied from the 2012 Visitor Study to determine if there were statistically significant differences between the visitor groups (e.g., Visitor Study [VS] and BBNE attendees). Both scale questions in the online survey were analyzed in EQS 6.1 to implement a Confirmatory Factor Analysis (CFA). EQS 6.1 was used to determine fit indices, factor loadings, measurement variance, and independence for festival (event) and novelty seeking motivations (Price, Blacketer, and Brownlee, 2018; Byrne, 2008). The CFA was used to validate the modified scales, and to group item responses together into the dimensions that contribute to Novelty Seeking or Festival Motivations at the festival. Finally, multiple regression analysis was completed in SPSS between perceptions and 
expectations of crowding and responses on the Novelty Seeking Scale in order to understand if motivations for novelty seeking were related to perceptions and expectations of crowding at the Fireflies Festival.

Interviews were audio recorded on a Sony IC Recorder LPEC mp3, transcribed into Microsoft Word 2016 software, and analyzed in Microsoft Excel 2016 Spreadsheet Software. Open-ended responses were coded into main themes and quantified into frequencies for each question. Because validity and reliability are key components within the trustworthiness of qualitative research, the researcher implemented certain methods to increase both within the study (Rose \& Johnson, 2020). The interview script mirrored important topics within the survey, and the interviews were recorded and transcribed to help increase reliability of the themes and findings. Moreover, the themes for the codes were clearly defined so that data analysis was consistent within the coding Excel workbook. For increased validity, the researcher reflected on their hidden assumptions of the project and role as part of the research instrument (Rose \& Johnson, 2020). Lastly, quotes included within the results often encompassed multiple codes and offered rich descriptions of the interviewees' experience at the Fireflies Festival. 


\section{Chapter Four:}

RESULTS

\section{Description of the Sample}

During data collection, the researcher approached 508 Festival attendees to participate in the survey and 49 attendees to participate in the phone interview, of whom 314 people elected to participate in the online survey and 27 of whom elected to participate in the phone interview (i.e., every tenth person). This yielded a response rate of $61.7 \%$ for the surveys and $55.1 \%$ for the phone interviews (estimated $5.4 \%$ confidence interval for the surveys at the $95 \%$ confidence level). Between the two sample groups, most festival attendees stated that they reside in South Carolina (76.6\%), with a majority of people living in the nearby Columbia area (55.2\%). The median household size for the survey respondents was 2.4 , with $81.2 \%$ reporting that their highest level of education was a Bachelor's or Graduate degree, and the annual household income before taxes was reported as a bimodal distribution with most responses being between $\$ 50,000$ - $\$ 74,999$ $(n=59,18.8 \%)$ and between $\$ 100,000-\$ 149,99(n=64,20.4 \%)$. Attending the Fireflies Festival was the first time a majority of the survey respondents $(58.0 \%)$ visited Congaree National Park, however, a majority of interview respondents $(63.0 \%)$ stated that they have visited the park before.

\section{BBNE Participants' Motivations, Trip Characteristics, and Sociodemographics (RQ1)}

To understand if there were any statistical differences between BBNE attendees and general park visitors, the BBNE survey responses were compared to a visitor study 
(VS) conducted at Congaree National Park from 2011 to 2012 (Begly, Le, \& Hollenhorst, 2013) in order to identify any differing characteristics between BBNE and general CONG users (Manning, 2011). Although this visitor study was the last to be conducted at the park, it is important to note that there are some threats to internal validity when comparing to studies with differing methods, historical effects, and time differences. These, and other nuisance variables will be discussed in detail within the limitations of this study. Therefore, these findings may not be as definitive as they are perceived, even though many of the differences align with findings from other nature-based event research. The two groups (BBNE Participants and VS Participants) were found to have statistically significant differences in how they obtained information $\left(X^{2}(12)=333.410\right.$, $\mathrm{p}<.0001)$, highest level of education $\left(X^{2}(3)=10.157, \mathrm{p}=.017\right)$, annual household income before taxes $\left(X^{2}(8)=30.287, \mathrm{p}<.0001\right)$, and state of residence $\left(X^{2}(9)=48.540\right.$, $\mathrm{p}<.0001)$. These differences are similar to previous visitor types, where natural event visitors have higher levels of education and income (Kruger et al., 2019; Kruger, Viljoen, \& Saayman, 2013).

For how the groups obtained information, post hoc analysis involved pairwise comparisons using multiple z-tests of two proportions with a Bonferroni correction. Statistical significance was accepted at $\mathrm{p}$ due to the increased risk of a Type I error as the dependent variable included numerous categories for comparison (i.e., DV $=$ how the groups obtained information; Laerd, 2017). BBNE Participants obtained information from "Friends/relatives/word of mouth" ( $\mathrm{n}=169,21.2 \%$ versus 324, 15.1\%), "Social media" $(\mathrm{n}=97,12.2 \%$ versus $\mathrm{n}=12,0.6 \%)$, and "Newspaper/magazine articles" $(\mathrm{n}=70$, 
$8.8 \%$ versus $n=81,3.7 \%$ ) at a statistically higher rate than VS participants, $\mathrm{p}<.001$. For highest level of education, the analysis was the same as how the group obtained information, except the statistical significance was accepted at $\mathrm{p}<.0125$ after the Bonferroni correction. BBNE participants had higher levels of education compared to VS Participants, wherein the "High School Diploma/GED" level $(n=74,6.0 \%$ versus $n=7$, $2.3 \%$ ) was greater for VS participants, $p=.009$. For annual household income before taxes, the analysis was similar to the previous questions, except statistical significance was accepted at $p<.0056$. There were statistically significant differences in the proportion of BBNE participants whose annual household income before taxes was " $\$ 200,000$ or More" $(n=31,9.9 \%$ versus $n=48,4.0 \%)$ than VS Participants, $p<.001$ There were no significant differences in other visitor characteristics tested (i.e., number of people in household, number of nights spent visiting the park).

\section{Indicators That Lead to Quality BBNE Experiences (RQ2)}

Phone interviews were utilized to add richness and depth to the online surveys in this mixed- methods research design (Creswell \& Plano Clark, 2018; Manning, 2011). Data saturation, or the point in which emerging information becomes sparser, was reached within the 27 interviews collected (Hallo \& Manning, 2009; Marshall, 1996). Phone interviewees were asked what they liked most about the festival, and the response codes and frequencies are located in Table 1 . The most frequently recorded codes were "the fireflies themselves" and "the festival was well organized and easy to navigate." However, indicators must be measurable and manageable variables - and because 
fireflies are biological measures that are not directly related to visitor use — they are factors, not indicators (Manning, 2007). For example, Respondent 8 stated that "probably just the fireflies. And it was well set up, they had paths to take," were their most liked factors. Respondent 12, on the other hand, stated "I really liked how the way they had it blocked off, you could see relatively far into the forest and see actually how expansive the fireflies were back there. So that was my favorite part, being able to see the whole thing, not just a small little area." The former quote describes a factor of their experience (the fireflies) as well as a potential indicator (the design of the trail), while the latter only describes a potential indicator (the design of the trail).

Table 2 lists the codes for the least liked factors from the phone interviewees. The most frequently recorded codes between the two groups involved issues with crowds, specifically "being pushed by the crowds," "people who do not follow guidelines," and overall "crowding." Interview respondent 9 expressed frustration with the other attendees, stating "the least [enjoyable aspect] would be people who don't act the way they should and people who are loud or pushy. You know, there is just some people that don't experience it the way they should be because of the loud noise and stuff like that." Survey Respondent 20 mentioned that the current crowd control measures were not acceptable given the amount of visitors who ignored the park's guidelines, stating "larger groups completely oblivious to others and blocking the whole trail width and/or being loud [was the worst aspect]." When asked what elements decreased their visitor experience, $33.4 \%$ of the survey responses directly related to crowding as well (e.g., crowding, congestion on the trail, and human-caused noise), as seen in Table 3. 
This suggests that the design of the Fireflies Festival and the trail system greatly influences the visitor experience. Based on the recommendations for potential indicators (Manning, 2007), time or distance to access trail, use density at different sections of the trail, human-caused noise, and group size could be useful indicators for future Firefly Festival management.

\section{Event Motivations and Novelty Seeking Motivations (RQ1 \& RQ3)}

To better understand BBNE motivations to attend the Fireflies Festival, two motivation scales were included in the survey, which were analyzed via Confirmatory Factor Analysis (CFA). Byrne (2008) suggested the following acceptable levels of fit when interpreting fit indices: $\mathrm{SB}_{X} 2$ non-significant, $\mathrm{CFI}>0.9, \mathrm{NNFI}>0.90, \mathrm{SRMR}<$ 0.1 , and RMSEA $<0.08$.

Following these guidelines, the fit indices derived from the CFA for event (festival) motivations were deemed appropriate (see Table 4), as were the fit indices derived from the CFA on novelty seeking motivations (see Table 5), suggesting adequate measurement performance of both scales. The standardized estimates of the dimensions within the event (festival) motivation scale varied widely in their reliability as measures of their intended constructs, as seen in the Family Togetherness (0.95) and Event Novelty (0.38) (Byrne, 2008). A majority of the first order standardized factor loadings on the novelty seeking motivations scale were $>0.70$, which was deemed appropriate for their intended constructs (Byrne, 2008; Price, Blacketer, \& Brownlee, 2018). 
Reviewing the means and standard deviations within the event (festival) motivations scale, the Event Novelty dimension had the highest mean for BBNE attendees $($ mean $=6.2, \mathrm{SD}=0.8 ; 1=$ Strongly Disagree and $7=$ Strongly Agree) followed by the Family Togetherness (mean $=5.2, \mathrm{SD}=1.8$ ). However, it should be noted that the dimension of Family Togetherness only has two items, which influences the factor loadings and covariances for the factor loadings ( $\lambda=$ for Item 15 ; Kline, 2011). The means and standard deviations within the novelty seeking scale show that the dimension of Change in Routine was most important to $\mathrm{BBNE}$ attendees (mean $=5.9, \mathrm{SD}=0.8 ; 1=$ Strongly Disagree and $7=$ Strongly Agree). Overall, event (festival) $($ mean $=4.6)$ and novelty seeking $($ mean $=4.7)$ second order dimensions were considered motivators to attend, however, they were not strong motivators since 4 was the neutral response.

\section{Perceptions of Crowding (RQ3)}

In order to infer whether certain BBNE motivations influenced attendee perceptions of crowding, questions on crowding were included within the survey. Survey respondents were asked to rate the level of crowding they felt at the Fireflies Festival using a nine point Likert-type scale (Table 6;1 $=$ Not at All Crowded and $9=$ Extremely Crowded). This scale has been previously validated as a reliable means to measure crowding for over 30 years (Vaske \& Shelby, 2008). BBNE Participants reported that they expected to feel more crowded at the festival than they experienced (expected crowding: mean $=5.2, \mathrm{SD}=2.2$; experienced crowding: mean $=4.0, \mathrm{SD}=2.3$ ). 
A multiple regression was implemented instead of a structural regression model (SRM) because the dependent variables of expected and perceived levels of crowding are single items. Therefore, the modelling and regression was cleaner and less cumbersome with the multiple regression than with an SRM even though there are some redundant variables within the two regressions due to the correlation between the dependent variables. A multiple regression established that a person's scores from the Novelty Seeking Scale could statistically and significantly predict their expected crowding levels at the Fireflies Festival to a small degree, $F(3,309)=3.057, \mathrm{p}=.029$. Residuals were normally distributed as assessed by visual inspection of a normal probability plot. Factor Scores on the Novelty Seeking Motivation Scale accounted for $2.9 \%$ of the variation in crowding expectations with adjusted $\mathrm{R}^{2=} 1.9 \%$. The regression summary is located in Table 7. The regression equations for the dimensions were: predicted expected crowding $=4.29+.336 \times($ Change in Routine $), \mathrm{p}=.038 ;$ predicted expected crowding $=$ $4.29+-.229 \times$ (Surprise), $\mathrm{p}=.014$; predicted expected crowding $=4.29+-.045 \mathrm{x}$ (Boredom Alleviation), $\mathrm{p}=.618$. Therefore, the dimensions of Surprise and Change in routine significantly predicted expected crowding within novelty seeking motivations.

A linear regression established that a person's scores from the Novelty Seeking Scale could not significantly predict the perception of crowding levels at the Fireflies Festival, $\mathrm{F}(3,314)=.841, \mathrm{p}=.472$. Overall, the findings indicate while novelty-seeking motivations could predict some of the expected levels of crowding based on Surprise and Change in Routine factors, these motivations account for little of the variance. 
Furthermore, novelty-seeking motivations could not predict the perceived crowding experienced at the Firefly Festival.

The organization of the festival, especially the Fireflies Trail, influenced perceptions of crowding. Interview respondent 10 mentioned that they did not feel crowded because "People meandered at their leisure. Some just sat down as soon as the trail began, there were benches. I just thought the whole thing was laid out very well.” On the other hand, when festival attendance increased by the end of the firefly mating period, others did not have the same experience. Respondent 26 stated that they did feel overcrowded and overwhelmed because "...being that it was dark and people were moving, it was kind of like being herded." Respondent 18 felt more crowded at different areas on the Fireflies Trail than other areas.

Respondent 18: but as far as the flow and the management, there was one time when we went down under the bridge and around the backside where we were getting ready to enter back up into where the ranger station is and the visitor center is, it bottle-necked tremendously there for about ten to fifteen minutes and it was very, very claustrophobic there. But I could hear the volunteers on the walkie-talkies conveying that information back and forth and trying to manage the flow a little bit better. So they were certainly aware of it and trying to get people moved through there as quickly as they could.

Moreover, as the number of people at the festival increased, attendees were more likely to disregard rules and regulations. Respondent 26 explained that people did not adhere to the rules, stating "...there were a lot of people talking at different volumes, 
there were cellphones out, you know, it was distracting." People using cellphones was mentioned numerous times throughout the interviews as a negative factor for their festival experience, so the number of cell phones in use on the Fireflies Trail at one time could be a potential indicator that would directly tie back to the festival rules and regulations.

\section{Attitudes Toward Current and Potential Management Practices (RQ4)}

Survey respondents were asked to evaluate and rank three potential and the current management policy for future firefly festivals at Congaree National Park, where $1=$ Unacceptable and $2=$ Acceptable (See Table 8). The same management policies were then ranked, where $1=$ Most Preferred and $4=$ Least Preferred (see Table 9). BBNE Participants reported that management alternatives that included implementing a lotterybased permit system were unacceptable and least preferred (Alternative Three: mean $=$ $2.8, \mathrm{SD}=1.0,58.0 \%$ Unacceptable; Alternative Two: mean $=3.2, \mathrm{SD}=1.0,71.0 \%$ Unacceptable; Alternative One: mean $=2.0, \mathrm{SD}=1.0,23.9 \%$ Unacceptable; Current Approach: mean $=2.1, \mathrm{SD}=1.1,24.2 \%$ Unacceptable). Survey response codes to an open-ended question about management alternatives and their frequencies are located in Table 10, which shows that the top codes listed are that festival attendees either had no concerns about management alternatives (30.5\%) or that they thought a lottery system would be too exclusive (8.6\%).

Interview Respondents were not given these four management alternatives, but were asked if they have any suggestions for making the Fireflies Festival more enjoyable 
or managing it better (see Table 11).Without having suggested prices for potential management outcomes like those outlined in the survey, the response codes and frequencies focused on extending the Fireflies Trail but could not offer any other management actions. Respondent 21 recommended "The only thing that I can think about is whether they could make a longer — a slightly longer — path; that could potentially reduce the density of people." The other most frequent code related to the respondents not having any suggestions for management alternatives. 


\section{Chapter Five: DISCUSSION AND CONCLUSION}

As visitation increases during the firefly mating season at CONG, park staff have been forced to manage the natural process like an event. Even with these organizational changes, increasing use density within the festival is creating strains on the park staff, the firefly habitat, and the visitor experience. This research study aimed to understand who are attending the Festival and whether they differed from general park visitors, what potential indicators of the visitor experience could be implemented, whether noveltyseeking motivations were influencing festival attendees, and how attendees perceived the current and three potential management alternatives. The findings illuminate the complexity of managing a festival within parks and protected areas. Results suggest that the perceived level of crowding at the Fireflies Festival diminished the visitor experience for some attendees, however, almost $40 \%$ of survey participants stated that they would most prefer that the park kept its current management approach (Table 9). Visitor use indicators relating to the Fireflies Trail design may help alleviate some perceptions of crowding while still offering a similar level of use. BBNE visitor demographics and novelty seeking motivation factor scores align with previous research on nature-based events, validating this niche in the tourism market (Kruger, Saayman, \& Hull, 2019). Therefore, these research findings could be used to catalyze potentially untapped tourism development in rural or low-income areas while also educating visitors about conservation issues on both a local and national scale. 


\section{Resource Concerns and Recommendations}

A majority of the potential indicators for the CNP 2019 Synchronous Fireflies Festival stemmed from issues associated with use density on the Fireflies Trail (i.e., human-caused noise, an increase in rule breaking as visitation increased, and the overall feeling of being "herded" along the trail). Density of use on the Fireflies trail, either within separate management zones or throughout the trail, appears to be an important indicator for visitor experience at the festival (Pettengill et al., 2012). Festival organization and trail design can directly influence the perceptions of crowding (Hammit, Cole, \& Monz, 2015; Manning, 2007). Moreover, festival attendees differed in expected levels of crowding, as shown in the regression findings. As CONG is largely designated Wilderness, general park visitors may be less forgiving of crowding than BBNE attendees or may encounter lower quality visitor experiences during the Festival.

Levels of Service (LOS) is a transportation framework used by the Transportation Research Board, and this framework could be used to measure the quality of visitor experiences along the Fireflies trail. The LOS framework includes a range of condition classes from very acceptable (LOS A) to very unacceptable (LOS F), which implicitly utilizes indicators and thresholds for density of use (Pettengill et al., 2012). Therefore, park managers could seamlessly implement the LOS condition class framework into their indicators for quality visitor experiences within a Fireflies Festival Management Plan. Monitoring trail conditions will become increasingly crucial if use density within the Fireflies Festival continues to increase. This could be done using replicable trail transects to determine changes in trail health (Hammit, Cole, \& Monz, 2015). To facilitate visitor 
experiences that still protect the surrounding firefly habitat, the research team does not recommend expanding the Fireflies Trail through the forest underbrush even though it was the most common management suggestion from the interview respondents (17\%) because of the potential firefly habitat degredation.

Dispersal of use throughout the Fireflies trail is hindered by the surrounding firefly habitat; therefore, dispersal is limited to the existing trail system at CNP. Use dispersal can occur spatially or temporally, and the latter is the recommended method for the Fireflies Festival. Temporal use dispersion can help provide more opportunities for solitude along the Fireflies Trail, especially as the trail already includes an area for rest and reflection. As nighttime recreation offers unique experiences relating to soundscapes and the night sky, some BBNE participants may be motivated to attend by the opportunity to experience solitude at night or the increasingly scarce natural darkness (Beeco et al, 2011). Temporal dispersion of use may allow for more festival attendees to experience solitude within the designated resting area, thereby positively influencing their visitor experience. Event attendees were concerned about the limited access inherent within lottery and shuttle systems. Instead, length of time allowed on the Fireflies trail could be fixed at a half an hour per group to allow for full emersion into the experience. The shuttle system implemented during the last weekend of the Fireflies Festival used a similar fixed itinerary where each shuttle stopped at the festival for a predetermined amount of time, and all attendees who arrived on the shuttle had to leave on the same vehicle. If use density continues to increase at the festival and negatively impact the health of the Fireflies trail, park managers may need to consider re-routing the Fireflies 
trail onto the preexisting boardwalk. This suggestion, however, must include implementation of a use ration because the boardwalk infrastructure has a safety weight limit.

Use-ration systems are direct management practices that can successfully limit recreational demand (Manning, 2007). Managers must thoughtfully review the impacts and consequences of use rationing systems (Hammit, Cole, \& Monz, 2015). Three rationing systems - lottery, pricing, and shuttle reservations - were suggested as potential management actions. Implementing a free shuttle system most preferred management alternative, whereas implementation of a lottery system was the least preferred management option, and these opinions should be taken into consideration for future festivals. Because use limits are usually seen as more acceptable when they are explicitly implemented to prevent degradation of unique but finite natural resources from overuse, park managers should stress the preservation of firefly habitat when implementing a rationing system (Hammit, Cole, \& Monz, 2015). Implementing a shuttle reservation system that includes a time limit and the creation of multiple use zones (i.e., photography zone, reflection zone) along the fireflies trail is recommended as the best means to protect both the immersive visitor experience and the fragile firefly habitat.

\section{Visitor and Motivation Types}

The BBNE participant demographics and motivations to attend the Fireflies festival align with previous nature-based research. Natural event attendees and nature tourists tend to have relatively high incomes and levels of education, and festival 
attendees statistically differed from general park visitors in these aspects. Furthermore, major motivational push factors for both groups include escape from daily routine and novelty seeking (Kruger, Saayman, \& Hull, 2019). BBNE attendees at CNP scored highest on the change in routine factor, however, this phrasing was never explicitly stated within the research findings. Instead, attendees emphasized the spectacle of the fireflies themselves and the magical aura surrounding the experience. The research team recommends that this motivational factor within novelty seeking in natural events be renamed Discovering Uniqueness to fully capture the visitor experience.

Experiential factors at the Fireflies festival also parallel memorable experience factors found by Kruger and Saayman (2017). Their factors of accessibility, managed encounters and tranquility, splendor and amazement, photography, proximity, and authenticity were all mirrored within interview codes for the Fireflies Festival. For example, the organization of the festival, the helpful staff, and experiencing the unique spectacle were commonly stated factors for the Fireflies Festival. This further validates that natural event attendees are a niche segment within the tourism market which seeks experiences that are alternative to traditional tourist experiences (Kruger, Saayman, \& Hull, 2019; Kruger \& Saayman, 2017).

\section{Potential Implications for Tourism Development of BBNEs}

The overwhelmingly positive response from CNP Fireflies Festival attendees suggest that the festival, and BBNEs overall, could be an untapped potential for tourism development. Many people left the festival viewing the park as a "hidden gem" that 
people want to visit again. Nature-based attendees value educational experiences, and so park managers could improve current firefly interpretation by erecting more informational boards or video presentations, hosting scientific presentations on synchronous fireflies, and by offering guided tours during the festival for both the fireflies and for the rest of the park (Kruger \& Saayman, 2017). Mechanisms of education stem beyond interpretive messages during the Fireflies Festival. Childhood visitation to parks and protected areas influences awareness and visitation to NPS units during adulthood; therefore, educational outreach to schools and other youth communities is highly recommended (Xiao et al., 2018). Tourism development around the Fireflies Festival, and any other BBNE located within a rural area, could positively affect the economies of gateway communities. Culturally oriented marketing and interpretation may encourage African American visitation to the festival and to CONG overall (Xiao et al., 2018). Offering shuttle busses from culturally important places like local churches or partnering with nearby schools to create a nighttime field trip are some recommendations for park management. Natural spaces, while potential assets for sustainable development, can be quickly over-exploited if left unchecked (Talbot, 1998). Stakeholder awareness and perceptions of tourism are necessary for meaningful stakeholder participation in sustainable tourism development (Cárdenas, Byrd, \& Duffy, 2015). The Fireflies Festival is an opportunity for $\mathrm{CONG}$ to provide holistic, high-quality visitor experiences that benefit both festival attendees and the local community. The same may be true for other BBNEs. 


\section{Chapter Six:}

\section{LIMITATIONS AND FUTURE RESEARCH}

Although this study aims to understand visitor motivations to biologically-based nighttime events (BBNEs), the results have some threats to internal and external validity. For example, the research focused on the CNP Synchronous Fireflies Festival as the study location, but not all park management recommendations will be wholly generalizable for other BBNEs. The comparison to the 2012 VS also creates internal threats to the study. Changes in technology, historical effects between the two study year, and differences in methodologies are all nuisance variables that muddle the comparisons between the two studies and lessens the definitive differences between festival attendees and regular park visitors. A further limitation stems from the survey instrument, because the Event (Festival) Motivations scale caused a few difficulties when integrating it into the study. First, the Family Togetherness dimension contained only two items, which hindered measurement performance. Furthermore, when assessing the CFA, 5 of the 18 items loaded onto more than one component, and many items were not well represented within their dimension (e.g., "to observe the other people attending the festival" listed under the Thrills dimension). Future studies on BBNES may want to implement the scales used in the natural event research by Kruger and Saayman instead due to the issues experienced when analyzing the Event (Festival) Motivations scale and the stronger similarities within the event types (Kruger \& Saayman, 2016; Kruger, Saayman, \& Hull, 2019). Place attachment has been found to positively relate to perceptions of crowding, 
and mangers can increase place attachment at social events by showcasing diversity within the community (Wickham \& Kerstetter, 2000).

Moreover, place attachment directly links to conservation commitment and environmentally responsible behaviors, and park managers can foster these behaviors by educating festival attendees about conservation issues like night recreation impacts or degradation of fragile ecosystems like the bottomland forest (Lee, 2011). Future research should review the importance of place attachment at BBNEs and whether it could influence festival perceptions or increase visitation to the festival locations overall.

\section{BBNEs and Parks}

Despite many BBNEs occuring in parks and other protected areas, studies of these potentially impactful tourism opportunities are largely absent from the scientific literature. This study represents one of the first known investigations into BBNEs. BBNEs like the CNP Fireflies Festival can, as shown through the study reported here, attract visitors from afar to parks that might not otherwise come during the day. This can be important because parks are commonly surrounded by economically challenged areas. Some parks may not be well-utilized or appreciated by their surrounding communities, sometimes due to issues related to social justice. BBNEs could act as a bridge back to these parks for surrounding communities and for those who may have been displaced or feel unwelcomed. The study's findings also suggest that BBNEs can - when wellmanaged to minimize factors such as crowding - provide opportunities for people to fulfill their desires to experience novel and exciting aspects of our natural world. 
Experiences in parks such as seeing a flight of bats leaving a cave, kayaking among bioluminescent sea creatures, night hiking when owls call to each other, or observing hatching sea turtles racing for the ocean at night are truly singular occurrences for visitors that often create indelible memories. The spectacle of thousands of fireflies blinking in unison in a quiet, relatively uncrowded, and well-managed natural setting like Congaree National Park seemed to instill a sense of awe, appreciation, and interest in nature and park visitation among festival attendees in this study. In other parks or natural areas, perhaps even an ardent indoors person might be tempted to attend a BBNE because of its novelty, and in doing so find some appreciation for parks and their natural resources, all while contributing to the local economy. 


\section{REFERENCES}

Anderson, M., Kerstette, D., \& Graefe, A. (1998). The effects of festival attributes upon perceptions of crowding. In: Vogelsong, Hans G., comp, ed. Proceedings of the 1997 Northeastern Recreation Research Symposium. Gen. Tech. Rep. NE-241. Radnor, PA: US Department of Agriculture, Forest Service, Northeastern Forest Experiment Station. 182-185.

Aunger, R., \& Curtis, V. (2013). The anatomy of motivation: An evolutionary-ecological approach. Biological Theory, 8(1), 49-63. doi:10.1007/s13752-013-0101-7

Beeco, J., Hallo, J, Baldwin, E., \& McGuire, F. (2011). An examination of the guided night hiking experience in parks and protected areas. Journal of Park and Recreation Administration, 29(4), 72-88.

Begly, A., Le, Y., \& Hollenhorst, S. (2013) Congaree National Park Visitor Study 2011 2012. (Natural Resource Report NPS/NRSS/EQD/NRR—2013/634). Retrieved from the U.S. Department of the Interior, National Park Service.

Beh, A., \& Bruyere, B. L. (2007). Segmentation by visitor motivation in three Kenyan national reserves. Tourism Management, 28(6), 1464-1471. doi:10.1016/j.tourman.2007.01.010

Bernard, L., Mills, M., Swenson, L., \& Walsh, R. (2005). An evolutionary theory of human motivation. Genetic, Social, and General Psychology Monographs, doi:10.3200/MONO.131.2.129-184 
Billock, J. (2018). This is the best place in North America to see synchronous fireflies. Smithsonian Online. Retrieved from https://www.smithsonianmag.com/ travel/best-place-north-america-see-synchronous-fireflies-180968432/

Burns, R., Arnberger, A., \& von Ruschkowski, E. (2010). Social carrying capacity challenges in parks, forests, and protected areas. International Journal of Sociology, 40(3), 30-50. doi:10.2753/IJS0020-7659400302

Byrne, B. (2008). Testing for multigroup equivalence of a measuring instrument: a walk through the process. Psicothema, 20(4), 872-883.

Cárdenas, D., Byrd, E., \& Duffy, L. (2015). An exploratory study of community awareness of impacts and agreement to sustainable tourism development principles. Tourism and Hospitality Research, 15(4), 254-266.

Chang, J., Wall, G., \& Chu, S. (. (2006). Novelty seeking at aboriginal attractions. Annals of Tourism Research, 33(3), 729-747. doi:10.1016/j.annals.2006.03.013

Creswell, J. \& Plano-Clark, V. (2017). Designing and conducting mixed methods research ( $3^{\text {rd }}$ ed.). California: SAGE Publications.

Dangi, T., \& Gribb, W. (2018). Sustainable ecotourism management and visitor experiences: Managing conflicting perspectives in Rocky Mountain National Park, USA. Journal of Ecotourism, 17(3), 338-358.

Dann, G. (1981). Tourist motivation: An appraisal. Annals of Tourism Research, 8(2), 187-219. doi:10.1016/0160-7383(81)90082-7 
D'Antionio, A., Monz, C., Newman, P., Lawson. Steve, \& Taff, D. (2013). Enhancing the utility of visitor impact assessment in parks and protected areas: A combined social-ecological approach. Journal of Environmental Management, 124, 72-81. doi:10.1016/j.jenvman.2013.03.036

Duriscoe, D. (2001). Preserving Pristine Night Skies in National Parks and the Wilderness Ethic. The George Wright Forum, 18(4), 30-36.

Fefer, J., De Urioste-Stone, S., Daigle, J., \& Silka, L. (2018). Understanding the perceived effectiveness of applying the visitor experience and resource protection (VERP) framework for recreation planning: A multi-case study in US National Parks. The Qualitative Report, 23(7), 1561-1582.

Fetters, M., Curry, L., \& Creswell, J. (2013). Achieving integration in mixed methods: Designs principles and practices. Health Services Research, 48(6pt2), 2134-2156. doi:10.1111/1475-6773.12117

ForestrySA (2019). Ghost Mushroom Lane- Visitor site now closed. Retrieved from: https://www.forestrysa.com.au/ghostmushrooms/

Gaston, K, Bennie, J., Davies, T., \& Hopkins, J. (2013). The ecological impacts of nighttime light pollution: a mechanistic appraisal. Biological reviews, 88(4), 912-927.

Getz, D. (1991). Festivals, Special Events, and Tourism. New York, USA: Van Nostrand Reinhold Press. 
Geus, S., Richards, G., \& Toepoel, V. (2016). Conceptualisation and operationalisation of event and festival experiences: Creation of an event experience scale. Scandinavian Journal of Hospitality and Tourism, 16(3), 274-296. doi:10.1080/15022250.2015.1101933

Gursoy, D., Uysal, M., Sirakaya-Turk, E., Ekinci, Y., \& Baloglu, S. (2015). Handbook of scales in tourism and hospitality research. Boston, MA: CABI.

Haas, G., (2001). Visitor Capacity in the National Park System. Social Science Research Review 2(1), 1-26.

Hallo, J. C., Manning, R. E., \& Stokowski, P. A. (2009). Understanding and managing the off road vehicle experience: Indicators of quality. Managing Leisure, 14(3), 195-209. doi:10.1080/13606710902944995

Hammitt, W., Cole, D., \& Monz, C. (2015). Wildland recreation: ecology and management ( $3^{\text {rd }}$ ed.) Hoboken, NJ: John Wiley \& Sons.

Hsu, C., Cai, L., \& Li, M. (2010). Expectation, motivation, and attitude: A tourist behavioral model. Journal of Travel Research, 49(3), 282-296. doi: $10.1177 / 0047287509349266$

Hsu, T., Tsai, Y., \& Wu, H. (2009). The preference analysis for tourist choice of destination: A case study of Taiwan. Tourism Management, 30(2), 288-297. doi:10.1016/j.tourman.2008.07.011 
Interagency Visitor Use Management Council. (2016). Visitor Use Management

Framework: A guide to providing sustainable outdoor recreation. ( $\left.1^{\text {st }} \mathrm{ed}.\right)$.

Iso-Ahola, S., \& Allen, J. (1982). The dynamics of leisure motivation: The effects of outcome on leisure needs. Research Quarterly for Exercise and Sport, 53(2), 141-149. doi:10.1080/02701367.1982.10605240

Iso-Ahola, S. (1982). Toward a social psychological theory of tourism motivation: A rejoinder. Annals of Tourism Research, 9(2), 256-262. doi:10.1016/0160-7383(82)90049-4

Jang, S., \& Feng, R. (2007). Temporal destination revisit intention: The effects of novelty seeking and satisfaction. Tourism Management, 28(2), 580-590. doi:10.1016/j.tourman.2006.04.024

Kline, R. (2011). Principles and practice of structural equation modeling (3rd ed.) Guilford Press.

Kruger, M., \& Saayman, M. (2017). An experience-based typology for natural event tourists. International Journal of Tourism Research, 19(5), 605-617. doi: $10.1002 /$ tr. 2133

Kruger, M., Saayman, M., \& Hull, J. (2019). A motivation-based typology for natural event attendees. Journal of Policy Research in Tourism, Leisure and Events, 11(1), 35-53. doi:10.1080/19407963.2018.1443939 
Kruger, M., Viljoen, A., \& Saayman, M. (2013). Who pays to view wildflowers in South Africa? Journal of Ecotourism, 12(3), 146-164. doi:10.1080/14724049.2013.871286

Kuentzel, W., \& Heberlein, T. (2003). More visitors, less crowding: Change and stability of norms over time at the Apostle Islands. Journal of Leisure Research, 35(4), 349-371. doi:10.1080/00222216.2003.11950001

Laerd Statistics (2017). Statistical tutorials and software guides. Retrieved from https://statistics.laerd.com/

Lee, T. (2011). How recreation involvement, place attachment and conservation commitment affect environmentally responsible behavior. Journal of Sustainable Tourism, 19(7), 895-915. doi:10.1080/09669582.2011.570345

Lee, T., \& Crompton, J. (1992). Measuring novelty seeking in tourism. Annals of Tourism $\backslash$ Research, 19(4), 732-751. doi:10.1016/0160-7383(92)90064-V

Lehto, X., O’Leary, J., \& Morrison, A. (2004). The effect of prior experience on vacation behavior. Annals of Tourism Research, 31(4), 801-818. doi:10.1016/j.annals.2004.02.006

Manning, R. (2007). Parks and carrying capacity: Commons without tragedy. Washington D.C., USA: Island Press.

Manning, R. (2011). Studies in outdoor recreation (3. ed.). Corvallis, OR: Oregon State Univ. Press. 
Manning, R. (2001). Visitor experience and resource protection: A framework for managing the carrying capacity of national parks. Journal of Park \& Recreation Administration, 19(1), 93-108.

Manning, R. \& Lawson, S. (2002). Carrying capacity as "Informed judgment": The values of science and the science of values. Environmental Management, 30(2), 157-168. doi:10.1007/s00267-002-2772-x

Manning, R., Lime, D., Hof, M., \& Freimund, W. (1995). The visitor experience and resource protection (VERP) process: The application of carrying capacity to Arches National Park. The George Wright Forum, 12(3), 41-55.

Manning, R., Rovelstad, E., Moore, C., Hallo, J., \& Smith, B. (2015). Indicators and standards of quality for viewing the night sky in the national parks. Park Science, $32(2), 1-9$.

Marion, J. (2016). A review and synthesis of recreation ecology research findings on visitor impacts to wilderness and protected natural areas. Journal of Forestry, 114(3), 352-362. doi:10.5849/jof.15-498

Marion, J., Leung, Y., Eagleston, H., \& Burroughs, K. (2016). A review and synthesis of recreation ecology research findings on visitor impacts to wilderness and protected natural areas. Journal of Forestry, 114(3), 352-362.

doi:10.5849/jof.15-498 
Marshall, M. (1996). Sampling for qualitative research. Family Practice, 13(6), 522-526. doi:10.1093/fampra/13.6.522

McCool, S., \& Freimund, W. (2016). Maintaining relevancy: Implications of changing societal connections to wilderness for stewardship agencies. Journal of Forestry, 114(3), 405 414. doi:10.5849/jof.14-140

Mehmetoglu, M. (2007). Typologising nature-based tourists by activity—Theoretical and practical implications. Tourism Management, 28(3), 651-660. doi:10.1016/j.tourman.2006.02.006

Miller, Z., Fefer, J., Kraja, A., Lash, B., \& Freimund, W. (2017). Perspectives on Visitor Use Management in the National Parks. The George Wright Forum, 34(1), 37-44.

Mitas, O., \& Bastiaansen, M. (2018). Novelty: A mechanism of tourists' enjoyment. Annals of Tourism Research, 72, 98-108.

Mowen, A., Vogelsong, H., \& Graefe, A. (2003). Perceived crowding and its relationship to crowd management practices at park and recreation events. Event Management, 8(2), 63 72. doi:10.3727/152599503108751711

National Park Service Organic Act of 1916, 16 U.S.C. §1 (1916).

National Park Service. (2019a). Bat flight program - Carlsbad Caverns National Park (U.S. National Park Service). Retrieved from https://www.nps.gov/cave/planyourvisit/bat_flight_program.htm 
National Park Service (2019b). Synchronous fireflies - Great Smoky Mountains national park (U.S. National Park Service). Retrieved from https://www.nps.gov/grsm/learn/nature/fireflies.htm

National Park Service. (2019c). Fireflies - Congaree National Park (U.S. National Park Service). Retrieved from https://www.nps.gov/cong/fireflies.htm

National Park Service. (2020). Visitation numbers (U.S. National Park Service). Retrieved from https://www.nps.gov/aboutus/visitation-numbers.htm

Park, M., Daniels, M. J., Brayley, R., \& Harmon, L. K. (2010). An analysis of service provision and visitor impacts using participant observation and photographic documentation: The national cherry blossom festival. Event Management, 14(2), 167-182. doi:10.3727/152599510X12766070301082

Pettengill, P., Manning, R., Anderson, L., Valliere, W., \& Reigner, N. (2012). Measuring and managing the quality of transportation at Acadia National Park. Journal of Park and Recreation Administration, 30(1), 68-84.

Price, S., Blacketer, M., \& Brownlee, M. (2018). The influence of place attachment on campers' evaluations of ecological impacts due to recreation use. Journal of Outdoor Recreation and Tourism, 21, 30-38. doi:10.1016/j.jort.2017.11.001 
Rose, J., \& Johnson, C. W. (2020). Contextualizing reliability and validity in qualitative research: toward more rigorous and trustworthy qualitative social science in leisure research. Journal of Leisure Research, 1-20.

doi: $10.1080 / 00222216.2020 .1722042$

Scott, D. (1995). A comparison of visitors' motivations to attend three urban festivals. Festival Management and Event Tourism, 3(3), 121-128.

Seidman, I. (2019). Interviewing as qualitative research: A guide for researchers in education and the social sciences (5th ed.) Teachers College Press.

Šimková, E., \& Holzner, J. (2014). Motivation of tourism participants. Procedia - Social and Behavioral Sciences, 159, 660-664. doi:10.1016/j.sbspro.2014.12.455

Smith, B., \& Hallo, J. (2013). A system-wide assessment of night resources and night recreation in the US National Parks: A case for expanded definitions. Park Science, 29(2), 54-59.

Stankey, G., Cole, D., Lucas, R., Petersen, M., \& Frissell, S. (1985). The limits of acceptable change (LAC) system for wilderness planning. (Gen. Tech. Report INT-176). Retrieved from https://www.cabdirect.org/cabdirect/abstract/19861835269

Talbot, C. (1998). The wilderness narrative and the cultural logic of capitalism. In The great new wilderness debate, Athens, GA: University of Georgia Press 325-329. 
Tohono Chul (2019). Queen of the Night. Retrieved from: https://tohonochul.org/?s=Queen+of+the+Night

Uysal, M., Gahan, L., \& Martin, B. (1993). An examination of event motivations: A case study. Festival Management and Event Tourism, 1(1), 5-10.

Vaske, J., \& Shelby, L. (2008). Crowding as a descriptive indicator and an evaluative standard: Results from 30 years of research. Leisure Sciences, 30(2), 111-126. doi:10.1080/01490400701881341

Ware, H., McClure, C., Carlisle, J., \& Barber, J. (2015). A phantom road experiment reveals traffic noise is an invisible source of habitat degradation. Proceedings of the National Academy of Sciences, 112(39), 12105-12109.

Warzecha, C. A., \& Lime, D. W. (2001). Place attachment in Canyonlands National Park: Visitors' assessment of setting attributes on the Colorado and Green Rivers. Journal of Park \& Recreation Administration, 19(1), 59-78.

Whittaker, D., Shelby, B., Manning, R., Cole, D., \& Haas, G. (2011). Capacity reconsidered: Finding consensus and clarifying differences. Journal of Park and Recreation Administration, 29(1), 1-20.

Wickham, T., \& Kerstetter, D. (2000). The relationship between place attachment and crowding in an event setting. Event Management, 6, 167-174. 
Xiao, X., Manning, R., Perry, E., \& Valliere, W. (2018). Public awareness of and visitation to national parks by racial/ethnic minorities. Society \& Natural Resources, 31(8), 908-924. doi:10.1080/08941920.2018.1448914

Xu, J., \& Chan, S. (2016). A new nature-based tourism motivation model: Testing the moderating effects of the push motivation. Tourism Management Perspectives, 18, 107-110. doi:10.1016/j.tmp.2016.01.001 
Appendix A: TABLES

Table 1

Codes assigned for INTERVIEW responses to the question "What did you like most about your visit to the Congaree National Park 2019 Fireflies Festival?"

\begin{tabular}{lc}
\hline Code & $\begin{array}{c}\text { Valid } \\
\text { Percent }\end{array}$ \\
\hline The fireflies themselves & 18.3 \\
The festival was well organized and easy to navigate & 18.3 \\
Uniqueness of it all was worthwhile & 13.3 \\
The amount of fireflies; the spectacle & 11.7 \\
$\begin{array}{l}\text { It was well-staffed with upbeat, hardworking people } \\
\text { There was a magical atmosphere }\end{array}$ & 6.7 \\
$\begin{array}{l}\text { The excitement of children who attended } \\
\text { The quietness of the crowd; it was peaceful }\end{array}$ & 5.0 \\
$\begin{array}{l}\text { Single Responses: There was low attendance during my visit; The availability of } \\
\text { other amenities that the park has to offer; Feeling safe thanks to EMS and the park } \\
\text { staff; Being able to show others the fireflies/the reaction of others; It was nostalgic/it } \\
\text { reminded me of childhood; It was free; People followed the rules and directions; } \\
\text { The intimacy of the experience; The staff were knowledgeable; Seeing the crowd; } \\
\text { The park is beautiful; I enjoyed the camping experience the most }\end{array}$ & 3.3 \\
\hline
\end{tabular}


Table 2

Codes assigned to the INTERVIEW responses to the question "What did you like least about the Fireflies Festival?"

$\begin{array}{cc} & \text { Valid } \\ \text { Code } & \text { Percent }\end{array}$

The crowding; being pushed by the crowds

There wasn't anything I didn't like; do not know

The mosquitos

People not following rules or using prohibited items

Parking was hard to navigate

Lacking more information about the science behind the fireflies

Rain or other poor weather

There was not enough management on the trail to keep visitors in check

It was noisy

It was difficult to see fireflies

Single Reponses: I did not visit during peak synchrony; Having to deal with my children; The staff was not wholly knowledgeable or gave conflicting answers; Lack of protection against possible mass shootings; Not being able to properly experience the fireflies; I was confused about where the trail started; Not being able to go on the boardwalk; I got stuck at the entrance; The shuttle system was inefficient; Lack of information on bringing children and/or large groups; The staff were testy and rude 
Table 3

Codes assigned to the $\underline{\boldsymbol{S U} \boldsymbol{R} \boldsymbol{V E} \boldsymbol{Y}}$ responses to the question "What did you like least about your visit to the Congaree National Park 2019 Fireflies Festival?"

Code

Valid

Issues relating to crowding (e.g., crowding, congestion, people being loud, people breaking rules)

Percent

Nothing

Issues relating to parking (e.g., parking, distance from parked car to trail entrance, pedestrians being directed to walk against traffic)

Issues relating to the organization of the festival (e.g., the poor handling of the shuttle system, lack of details available online, not many activities or attractions for kids, not enough educational information)

Issues relating to the fireflies trail (e.g., trail too short or narrow, lack of seating, uneven terrain, the boardwalk and other trails being closed off, confusion over who was allowed on the limited mobility path)

Weather related issues (e.g., heat, rain, or humidity that could lead to cutting the trip short)

Issues relating to festival staff (e.g., crowd control, rude volunteers or rangers, inconsistency of trail guidance, being herded or rushed through the trail)

Nature-based issues (e.g., mosquitos, did not see much wildlife, snakes on or near the trail)

Issues relating to portrayal of the festival (e.g., not as many fireflies as expected, overhyped or too commercialized)

Visitor-related issues (e.g., not being prepared, limited cell and GPS coverage, getting separated from their group, kids not being as excited as parents)

Issues relating to the visitors' center and bathrooms (e.g., no firefly shirts in the gift shop, film not showing, bathrooms being dirty or closed) 
Table 4

Factor loadings, item means, standard deviations, and fit indices for event (festival) motivations.

\begin{tabular}{|c|c|c|}
\hline Dimensions and items $s^{a}$ & $\lambda$ & Mean (SD) \\
\hline Escape (standardized estimate $\left.{ }^{\mathrm{b}}=0.34\right)$ & - & $4.5(1.5)$ \\
\hline To get away from the demands of life & 0.66 & $3.9(1.8)$ \\
\hline To have a change from my daily routine & 0.92 & $4.9(1.6)$ \\
\hline For a change of pace from everyday life & 0.95 & $4.8(1.6)$ \\
\hline Excitement $/$ Thrills $($ standardized estimate $=0.92)$ & - & $3.1(1.2)$ \\
\hline To be with people of similar interests & 0.76 & $4.3(1.7)$ \\
\hline Because I enjoy special events & 0.60 & $5.8(1.2)$ \\
\hline To observe the other people attending the festival & 0.43 & $2.4(1.5)$ \\
\hline Event Novelty (standardized estimate $=0.38$ ) & - & \\
\hline Event Novelty (standardized estimate $=0.38)$ & - & \\
\hline To experience new and different things & 0.64 & $6.2(0.8)$ \\
\hline Because I was curious & 0.57 & $6.2(0.9)$ \\
\hline Because I enjoy special events & 0.75 & $5.8(1.2)$ \\
\hline Because the Fireflies Festival is unique & 0.52 & $6.4(0.9)$ \\
\hline Socialization ( standardized estimate $=0.87$ ) & - & $4.1(1.6)$ \\
\hline So I could be with my friends & 0.57 & $4.4(2.0)$ \\
\hline For a chance to be with people who are enjoying themselves & 0.90 & $3.9(1.8)$ \\
\hline To be with people who enjoy the same things I do & 0.89 & $3.9(1.7)$ \\
\hline Family Togetherness $($ standardized estimate $=0.95)$ & - & $5.2(1.8)$ \\
\hline Because I thought my entire family would enjoy it & 1.00 & $5.2(1.9)$ \\
\hline So the family could do something together & 0.89 & $5.2(1.9)$ \\
\hline Second order factor: event (festival) motivations & & $4.6(0.9)$ \\
\hline
\end{tabular}

Notes: $\quad{ }^{a}$ Rated as agreement on a 7-point Likert scale $(1=$ strongly disagree, 7 = strongly agree $)$ with higher scores indicating higher escape, excitement/thrills, event novelty, socialization, or family togetherness; $\lambda=$ standardized factor loading; CFI = Comparative Fit Index; $d f=$ degrees of freedom; NNFI $=$ Non-Normed Fit Index; Reliability coefficient RMSEA = Root Mean Square Error of Approximation; SB $\chi^{2}=$ Satorra-Bentler Scaled Chi-Square; $S D=$ standard deviation; $\mathrm{SRMR}=$ Standardized Root Mean Squared Residual; $* p<0.05$

${ }^{\mathrm{b}}$ Standardized estimate between the dimension and the second order factor of event (festival)motivations. 
Table 5

Factor loadings, item means, standard deviations, and fit indices for novelty seeking motivations.

Dimensions and Items

Change in Routine (standardized estimate ${ }^{\mathrm{b}}=0.61$ )

I like to find myself at event destinations where I explore new things

I want to experience new and different things

I want to experience customs and cultures different from those in my own environment

My ideal recreational event involves looking at things I have not seen before

I want there to be a sense of discovery involved while participating in an event

I like to visit adventurous places

I feel a powerful urge to explore the unknown

Boredom Alleviation (standardized estimate $=0.70$ )

I want to travel or attend events to relieve boredom

I have to participate in events from time to time to avoid getting into a rut

I like to participate in events because the same work routine bores me

Surprise (standardized estimate $=0.62$ )

I do not like to plan an event trip in detail because it takes away from some of the unexpectedness

I like events that are unpredictable

I would like to participate in an event with no pre-planned routes in my mind

Second order factor: novelty seeking motivations $\lambda$

Mean (SD)

$5.9(0.8)$

$0.64 \quad 5.9(0.8)$

$0.73 \quad 6.2(0.9)$

$0.68 \quad 5.7(1.3)$

$0.72 \quad 5.9(1.1)$

$0.80 \quad 6.0(1.0)$

$0.72 \quad 6.1(1.0)$

$0.65 \quad 5.6(1.3)$

$4.3(1.5)$

$0.79 \quad 4.6(1.7)$

$0.86 \quad 4.3(1.8)$

$0.82 \quad 4.1(1.7)$

- $\quad 4.0(1.4)$

$0.75 \quad 3.8(1.7)$

$0.85 \quad 4.1(1.6)$

$0.75 \quad 4.1(1.7)$

$\mathrm{CFI}=0.971 ; \mathrm{NNFI}=0.962 ; \mathrm{RMSEA}=0.045 ; \mathrm{SB} \chi^{2}(d f)=98.2549 *(60) ; \mathrm{SRMR}=0.049$

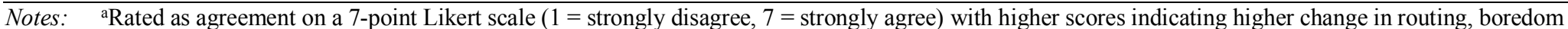
alleviation, or surprise; $\lambda=$ standardized factor loading; CFI = Comparative Fit Index; $d f=$ degrees of freedom; NNFI = Non-Normed Fit Index; Reliability coefficient RMSEA = Root Mean Square Error of Approximation; SB $\chi^{2}=$ Satorra-Bentler Scaled Chi-Square; $S D=$ standard deviation; SRMR = Standardized Root Mean Squared Residual; * $p<0.05$.

${ }^{\mathrm{b}}$ Standardized estimate between the dimension and the second order factor of novelty seeking motivations. 
Table 6

Responses for levels of crowding experienced at the Fireflies Festival.

\begin{tabular}{|c|c|c|c|c|c|c|c|c|c|c|c|c|}
\hline \multirow[b]{2}{*}{ Issue } & \multicolumn{12}{|c|}{ Valid Percent } \\
\hline & $\begin{array}{c}\text { Not at All } \\
\text { Crowded } \\
\text { (1) }\end{array}$ & (2) & (3) & (4) & (5) & (6) & (7) & (8) & $\begin{array}{c}\text { Extremely } \\
\text { Crowded } \\
\text { (9) }\end{array}$ & $\begin{array}{c}\text { Don't } \\
\text { Know or } \\
\text { Not } \\
\text { Applicable }\end{array}$ & Mean & $S D$ \\
\hline $\begin{array}{l}\text { How crowded did you expect } \\
\text { to feel at the festival? }\end{array}$ & 4.8 & 5.4 & 13.1 & 13.7 & 22.6 & 10.8 & 10.8 & 8.0 & 8.9 & 1.9 & 5.2 & 2.2 \\
\hline $\begin{array}{l}\text { How crowded did you feel on } \\
\text { the firefly trail? }\end{array}$ & 15.6 & 9.6 & 15.0 & 8.0 & 12.1 & 12.7 & 14.0 & 4.8 & 7.3 & 1.0 & 4.6 & 2.5 \\
\hline $\begin{array}{l}\text { How crowded did you feel } \\
\text { overall at the festival? }\end{array}$ & 18.2 & 14.0 & 13.7 & 13.1 & 15.3 & 10.5 & 7.6 & 3.5 & 3.8 & 0.3 & 4.0 & 2.3 \\
\hline $\begin{array}{l}\text { How crowded did you feel } \\
\text { while parking? }\end{array}$ & 30.9 & 13.1 & 11.8 & 9.6 & 8.6 & 6.7 & 5.1 & 1.9 & 6.1 & 6.4 & 3.4 & 2.5 \\
\hline
\end{tabular}


Table 7

Regression analysis summary for novelty seeking motivations predicting expected levels of crowding.

\begin{tabular}{lccccc}
\hline Variable & $\mathbf{B}$ & $\mathbf{9 5 \%} \mathbf{C I}$ & $\boldsymbol{\beta}$ & $\mathbf{t}$ & $\mathbf{p}$ \\
\hline Constant) & 3.791 & $(2.525,5.057)$ & & 5.893 & .000 \\
Scale Composite & .041 & $(-.221, .393)$ & .017 & .312 & .756
\end{tabular}

Note: $\quad \mathrm{R}^{2}$ adjusted $=-.003 . \mathrm{B}=$ standardized coefficient. $\mathrm{CI}=$ confidence interval for $\mathrm{B}$. 
Table 8

Acceptability of potential and current management actions.

\begin{tabular}{|c|c|c|}
\hline \multirow[b]{2}{*}{ Alternatives } & \multicolumn{2}{|c|}{ Valid Percent } \\
\hline & $\begin{array}{c}\text { Unacceptable } \\
\text { (1) }\end{array}$ & $\begin{array}{c}\text { Acceptable } \\
\text { (2) }\end{array}$ \\
\hline $\begin{array}{l}\text { Potential Alternative One: Implement a shuttle between parking at local } \\
\text { churches and the park. A } \$ 2.00 \text { round-trip, per-person fee will be collected } \\
\text { when boarding the shuttle. The shuttle may help decrease waiting lines, } \\
\text { parking times, and/or longer walks to the festival entrance. The shuttle may } \\
\text { decrease automobile noise and light impacts near the Fireflies Trail. The shuttle } \\
\text { would not cap the total number of visitors to the festival. It might allow more } \\
\text { people to come to the festival. However, if the number of people at the festival } \\
\text { continues to be high or grows it may result in more people on the trail, visitor- } \\
\text { created issues, less availability of staff, and harm the park itself. }\end{array}$ & 23.9 & 76.1 \\
\hline $\begin{array}{l}\text { Potential Alternative Two: Implement a lottery system to cap the total number } \\
\text { of visitors on any night of the Firefly Festival. The current available parking } \\
\text { would be used as a basis for this cap. Visitors would choose dates of their visit. } \\
\text { Lottery winners would be charged a } \$ 25.00 \text { reservation fee per vehicle to help } \\
\text { cover the cost of awarding permits, viewing supplies, and nightly personnel to } \\
\text { manage the viewing opportunity. The lottery would allow the park staff to } \\
\text { provide greater opportunities for solitude, natural quiet and darkness, less } \\
\text { conflicts with other visitors, easier parking, and an overall higher quality } \\
\text { experience at the festival. However, substantially less people than currently } \\
\text { attend the festival would be able to visit because of the availability of existing } \\
\text { parking. }\end{array}$ & 71.0 & 29.0 \\
\hline $\begin{array}{l}\text { Potential Alternative Three: The shuttle and lottery described above would be } \\
\text { combined. Their benefits, drawbacks, and costs would remain the same as } \\
\text { described above. This management approach would be the same as that used } \\
\text { for another firefly event at another national park. It would allow park staff to } \\
\text { better manage the festival overall and to help ensure adequate parking, reduce } \\
\text { issues, protect the park itself, and to provide higher quality experiences for } \\
\text { visitors during the event. It would cap the total number of visitors to the firefly } \\
\text { event, but because church parking is used it could potentially accommodate the } \\
\text { same number of festival visitors, or more. }\end{array}$ & 58.0 & 42.0 \\
\hline $\begin{array}{l}\text { Current Approach: Keep with current management approach, which does not } \\
\text { include a lottery or shuttle system. The festival will remain without fees and } \\
\text { will continue to rely on park staff and volunteers to manage visitors and } \\
\text { parking. As available parking is taken, vehicles will park along the entrance } \\
\text { road. This creates waiting times for parking and longer walks to the festival } \\
\text { entrance. This approach does not cap use. It creates the most opportunities for } \\
\text { visitors to access the festival. However, if the number of people at the Fireflies } \\
\text { Event continues to be high or grows it may result in more people on the trail, } \\
\text { visitor-created issues, less availability of staff, and harm the park itself. }\end{array}$ & 24.2 & 75.8 \\
\hline
\end{tabular}


Table 9

Ranking of potential and current management actions.

\begin{tabular}{|c|c|c|c|c|c|c|}
\hline \multirow[t]{2}{*}{ Alternatives } & \multicolumn{6}{|c|}{ Valid Percent } \\
\hline & $\begin{array}{c}1 \\
(\text { Most } \\
\text { Preferred })\end{array}$ & 2 & 3 & $\begin{array}{c}4 \\
\text { (Least } \\
\text { preferred) }\end{array}$ & Mean & $S D$ \\
\hline $\begin{array}{l}\text { Potential Alternative One: } \\
\text { implement a shuttle system } \\
\text { only }\end{array}$ & 36.7 & 35.5 & 16.9 & 10.9 & 2.0 & 1.0 \\
\hline $\begin{array}{l}\text { Current Management } \\
\text { Approach }\end{array}$ & 39.0 & 32.6 & 12.1 & 16.3 & 2.1 & 1.1 \\
\hline $\begin{array}{l}\text { Potential Alternative Three: } \\
\text { implement both a lottery and } \\
\text { shuttle system }\end{array}$ & 17.0 & 16.0 & 38.1 & 28.8 & 2.8 & 1.0 \\
\hline $\begin{array}{l}\text { Potential Alternative Two: } \\
\text { implement a lottery system } \\
\text { only }\end{array}$ & 8.6 & 12.8 & 30.0 & 48.6 & 3.2 & 1.0 \\
\hline
\end{tabular}


Table 10

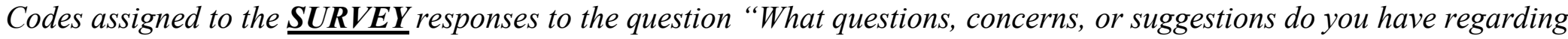
the potential alternatives listed in the previous question (Congaree National Park may consider potential alternatives in the future to guide visitor access and management of the Fireflies Festival.

Code

Valid

Percent

No concerns or do not know

A lottery system is too exclusive

The (lottery) cost is too expensive for families and low income communities

Keep the current approach

Implement a shuttle system; The current approach is unsustainable for the park and wildlife

The festival should be free; A (capped) reservation system should be implemented

The only acceptable option is a nominal fee; The park should do what they deem necessary to protect the fireflies

Vary or decrease the price point (e.g. day of week, national park pass holders, local community members, per car not per person)

Neither a shuttle or lottery allows for spontaneous trip planning; Implement a lottery

The fairgrounds is an unsavory place to hold the shuttle transportation system (e.g., pickpockets, location)

Other responses: Have a ranger stand guard at the trail entrance to limit trail use and disperse crowding; Expand the parking lot and trails; Implementing a lottery would be difficult at a small park; A shuttle will decrease the visitor experience; Implement something so that only those interested will attend (e.g., a live feed, a fee); Increase the times slots on the lottery or shuttle to allow for more visitors; Only run the lottery and shuttle on the weekends; Advertise day trips to the public so they can get better parking and view more of the park; Advertise "slow days" and carpooling; Divide the festival into photography and non-photography days; Make it first come, first served; Do not implement a lottery like at The Great Smoky Mountains NP because people do not like that one; Have more shuttle busses running; Communicate better between parking staff and visitors; Do not use recreation.gov to implement the system; First come, first served implementation is not inclusive; Both a lottery and a shuttle should be implemented, but at a lower cost; Locals would ignore the lottery and visit anyway; A lottery cannot determine a person's passion for fireflies; Contact the National Park Association for funding; There should be a hike-in option; Do not limit the festival because it is the only time the park is has an influx of first-time visitors 
Table 11

Codes assigned to the INTERVIEW responses to the question "What do you think about the way Congaree National Park manages the event? Do you have any suggestions or concerns?"

\section{Code}

Valid

\section{Code}

Percent

Increase the Fireflies Trail throughout the park

62.9

Implement better parking so that people are not walking long distances to their vehicles

Increase educational opportunities during the festival

Utilize the boardwalk for the Fireflies Trail

Manage the festival similar to what is done in The Smokies

Single responses: Have a walkway for pedestrians so that they are not walking in the road into oncoming traffic;

There was too much dead time between parking and viewing the fireflies; Increase shuttle advertising to encourage visitor use; Decrease the wait time to get on and pay for the shuttle; Increase signage around and within the festival so that people do not get disoriented; Enforce some crowd control so that the trail does not get congested with visitors

Negative or Neutral Responses

I cannot offer any suggestions

I think the park is managing it as best as they can 


\section{REFLECTION}

This thesis is a product of my place attachment to CNP, my interest in visitor use management, and my thesis committee chair allowing me to pursue my interests even without project funding — of which I am eternally grateful. Yet this thesis is also a product of my fears and insecurities. Fear that I was wasting my committee's time with a project that no one asked for, fear that my results are only marginally significant and I am upselling them, fear that I am a fraud within this research community I've grown to call home. But none of those fears are true (hopefully). Looking back, this process was more about personal growth than professional.

Throughout most of my adult life, I stopped thinking of myself as separate from the work I was producing. If my work was not perfect, then there was something wrong with me. Imperfection was a weakness, one I could not handle. This notion spawned from high school and kept festering until I would inevitably breakdown. I started last year believing that I was too busy, or too prideful, to make friends during this brief program. Looking back, I know this was a mechanism to protect others if I had a messy mental break. Thankfully, that did not occur. Instead, I ended up in the CAPS office. My family has always thought poorly of therapy, believing it to be an unnecessary sign of weakness that one could not handle themselves. I was afraid of everything —of being weak, of needing therapy, and, most importantly, what I might do without it. I went regardless. Throughout this experience, I am most grateful for this final push to seek help. I am in the best headspace I have ever been in, even though intrusive thoughts and self-doubt still 
linger, they no longer dominate my mind. It also helped shift my thinking from fearing imperfection to being willing and interesting in learning and bettering myself.

Changing my mindset allowed me to focus my perfectionism onto my thesis, with varying levels of success. I loved the challenge of creating my own research project; however, there are some things I would change. Collecting data alone was intimidating, to say the least. Each day when I would drive into CNP before the festival at six pm, the parking staff were already helping people park along the road because the parking lots were full. Everyone was waiting for dusk to settle, and were getting antsy in the muggy, hot summer heat. Talking to strangers is not something I am comfortable with, but in this case, I had to. That first week I would try to kill as much time as I could before the festival started gathering my supplies or talking to the park staff that I knew from my time as an intern there, or simply hiding in the bathroom trying to calm my nerves. Although the collection period was around only four hours a night, it felt like an exhausting lifetime. And as visitation increased, I realized that there was a physical limit to how many people I could talk to during that time. Even though I did not like collecting data, I knew the original nine days would not provide a sufficient sample size. With the goal of collecting information from 600 attendees (thanks to a conversation with my therapist) data collection became a fun challenge, and by the end of the festival I had grown to even enjoy it. Since then, I have happily helped with two other data collections and plan on joining another over the summer.

I wish I were as fond of the phone interview process. I think I was able to get a decent amount of richness from the interviews, however, I know they were subpar at best 
because of my limitations. I did not fully grasp the importance of the conversation itself, and was too caught up in asking the questions and getting answers I thought worked, and so the interviews are essentially verbal surveys. If I could redo this entire process, I would because then I could redo them. Since data analysis, I have worked on another research project that successfully implemented phone interviews. I know that I have grown as a researcher and can conduct rich interviews, I simply wish I could have done the same for my thesis. I felt the most out of my depth during the interview process, since I had little guidance on how to conduct them outside of following the script. Although I am glad I have this skill now, I think it would have greatly contributed to the mixedmethod design of this study.

Even with these shortcomings, I think this study contributes to the leisure research knowledge base as well as Congaree's festival management. The festival attendees were found to be similar to nature-based attendees instead of regular park visitors, reiterating that this is a distinct market niche within tourism—one that can catalyze economic growth for the gateway communities around BBNEs. This study also provides specific recommendations for the Fireflies Festival management, and although this is not as generalizable as the other findings, I am most proud of this.

I first learned about Congaree National Park during my undergraduate years in Columbia, SC, at the University of South Carolina. I was an officer of the outdoor club on campus, and I distinctly remember being told that there was a national park less than an hour away from campus, but it was "nothing special" and so we rarely visited except for last-minute day trips. 
Later I found out this aversion was caused by a previous group's run-in with law enforcement when camping. It was a few years later in my senior year that I truly became attached to the park. I started volunteering at the Visitors' Center, my senior project was about the African American narratives within the park, I interned as their Wilderness Fellow, and I helped write the Historic Research Survey for the park and surrounding area. At times I feared I was being too biased during my thesis, especially as I originally wanted to show that the park staff was handling the visitation boom as best they could. In the end I am afraid I was too harsh, too negative on what could be improved, but that is merely a product of my own sense of 'tough love'. As long as the Park and its wonderful staff benefit from this study, then I will be happy with its success.

The past two years have been the longest and shortest of my life. I naively thought graduate school would be a seamless extension to undergraduate-level work, but I was sorely mistaken. It was disorienting to have to put so much effort into schoolwork again, although I quickly grew to cherish that because I was learning so much in such a short time. I tend to thrive in fast-paced, challenging environments, and so I value my time at Clemson for helping me realize that I could visualize myself enjoying a life in academia. I also cherish the connections I have made here, within the department and in the Parks Solutions Lab. It was wonderful to be surrounded by like-minded people who strive to produce their best quality of work.

My time at Clemson University was spent being challenged by the esteemed professors and other graduate students alike. Every class was fulfilling, and each staff member I have met wants the department, and myself, to reach its highest potential. I am 
thankful for my time here, especially as it has opened so many doors. I can proudly say that I will be moving forward with pursuing a doctoral degree under my dream research project. Without my time at Clemson, I would not have the skillset nor experience required for that position.

My hope for this study is that it catalyzes more research into nighttime events within parks and protected areas. I hope that these events can be used to bolster local economies of gateway communities, and bridge gaps between public lands and their constituents. I hope that the suggestion of renaming a factor within novelty-seeking motivations from Change in Routine to Discovering Uniqueness is useful for future researchers who seek to describe the uniqueness of nature-based tourism events. Lastly, I hope that more people come to value Congaree National Park for its subtle beauty and rich history.

Within the upcoming years, I look forward to continuing to collaborate with the people I have meet at Clemson, both the professors and my cohort. It is exciting to know that we are the future of parks research, and that we will contribute to bettering parks and protected areas everywhere. 